\title{
The phylogeny of crested newts (Triturus cristatus superspecies): nuclear and mitochondrial genetic characters suggest a hard polytomy, in line with the paleogeography of the centre of origin
}

\author{
J.W. Arntzen ${ }^{1}$, G. Espregueira Themudo ${ }^{1,2}$, B. Wielstra ${ }^{1,3}$ \\ ${ }^{1}$ National Museum of Natural History, P. O. Box 9517, 2300 RA Leiden, The Netherlands, arntzen@nnm.nl \\ ${ }^{2}$ CIBIO, Centro de Investigação em Biodiversidade e Recursos Genéticos, Campus Agrário de Vairão, 4485-661 \\ Vairão,Portugal, themudo@mail.icav.up.pt \\ ${ }^{3}$ Institute of Biology Leiden, Leiden University, P.O. Box 9516, 2300 RA Leiden, The Netherlands, wielstra@natu- \\ ralis.nl
}

Key words: allozymes, historical biogeography, mitochondrial DNA-sequences, Triturus macedonicus, Triturus marmoratus, vicariance

\begin{abstract}
Newts of the genus Triturus (Amphibia, Caudata, Salamandridae) are distributed across Europe and adjacent Asia. In spite of its prominence as a model system for evolutionary research, the phylogeny of Triturus has remained incompletely solved. Our aim was to rectify this situation, to which we employed nuclear encoded proteins (40 loci) and mitochondrial DNA-sequence data (mtDNA, 642 bp of the ND4 gene). We sampled up to four populations per species covering large parts of their ranges. Allozyme and mtDNA data were analyzed separately with parsimony, distance, likelihood and Bayesian methods of phylogenetic inference. Existing knowledge on taxonomic relationships was confirmed, including the monophyly of the genus and the groups of crested newts (four species) and marbled newts (two species). The genetic coherence of species and subspecies was also confirmed, but not always with high statistical support (depending on taxon, characters under consideration, and method of inference). In spite of our efforts we did not obtain sufficient phylogenetic signal to prefer one out of twelve potential topologies representing crested newts relationships. We hypothesize that the lack of phylogenetic resolution reflects a hard polytomy and represents the (near)-simultaneous origin of crested newt species. Using a calibration point of $24 \mathrm{Ma}$ (million years before present) for the most recent common ancestor of Triturus-species, the crested newt radiation event is dated at 7-6 Ma (scenario 1) or at 11-10 Ma (scenario 2), depending on the application of an allozyme versus mtDNA molecular clock. The first biogeographical scenario involves the spread of crested newts from the central Balkans into four compass directions. This scenario cannot be brought into line with potential vicariance events for south-eastern Europe. The second scenario involves the more or less simultaneous origin of four species of crested newts through large-scale vicariance events and is supported by the paleogeographical reconstruction for the region at the end of the Middle Miocene. The subspecies Triturus carnifex macedonicus carries in one large area the mtDNA that is typical for the neighbouring species T. karelinii, which is attributed to introgression and a recent range shift. It is nevertheless a long distinct evolu-
\end{abstract}

tionary lineage and we propose to elevate its taxonomic status to that of a species, i.e., from Triturus c. macedonicus (Karaman, 1922) to Triturus macedonicus (Karaman, 1922).

\section{Contents}

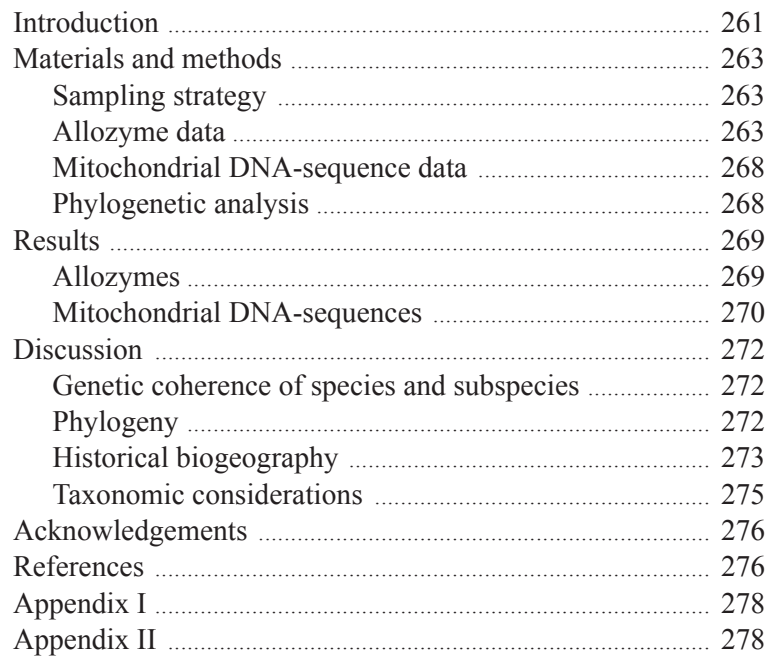

\section{Introduction}

The newt genus Triturus Rafinesque, 1815 (Amphibia, Caudata, Salamandridae) is a model group for various lines of evolutionary research, on e.g. locomotion (Gvozdik and van Damme, 2006), cranial ontogeny (Ivanović et al., 2007), reproductive behaviour (Steinfartz et al., 2007) and sexual size dimorphism (A. Ivanović, K. Sotiropoulos, M. Furtula, G. Džukić and M.L. Kalezić, submitted). Considering the efficient use 
of the 'comparative method' that aims to account for non-independence among characters due to shared evolutionary histories (Harvey and Pagel, 1991), it would seem important that the phylogenetic relationships within the group are well resolved. Despite considerable efforts, starting with the osteological study of Bolkay (1928), an unambiguous phylogenetic resolution for Triturus has not been obtained (Arntzen, 2003).

The genus Triturus encompasses six species of socalled 'large bodied' newts that are organized in two groups: the marbled newts with two species and the crested newts with four species. Marbled newts are characterized by a dorsal green colouration and a fairly uniform light grey or black underside. Triturus marmoratus (Latreille, 1800) occurs in central and southern France and the northern part of the Iberian Peninsula and T. pygmaeus (Wolterstorff, 1905) is confined to the south-western and southern parts of the Iberian Peninsula. Crested newts are characterized by an orange and black spotted ventral colouration and a dark backside and occupy most other parts of Europe and adjacent Asia. Four species are recognized: T. cristatus
(Laurenti, 1768), that is distributed over central, western and northern Europe and eastwards deep into Russia, T. carnifex (Laurenti, 1768), that occurs on the Appenine Peninsula and part of the Balkans, T. dobrogicus (Kiritzescu, 1903), that is confined to the Pannonian and Dobrogean lowlands, and T. karelinii (Strauch, 1870), with a range from the southern Balkans to the Caspian Sea. Triturus carnifex has two allopatric subspecies, the nominotypical subspecies in the western part and T. c. macedonicus (Karaman, 1922) in the eastern part of the species range, separated by the Adriatic Sea and the area approximately coinciding with Bosnia-Herzegovina.

Given their contiguous parapatric ranges with limited hybridization (Wallis and Arntzen, 1989), the four species of crested newt are conveniently referred to as a superspecies (or 'Artenkreis') sensu Rensch (1929). Molecular phylogenetic studies corroborate the monophyly of Triturus and the sistergroup relationship of crested and marbled newts (e.g. Zajc and Arntzen, 1999; Steinfartz et al., 2007). Approximate geographical distributions of Triturus species are shown in Figure 1.

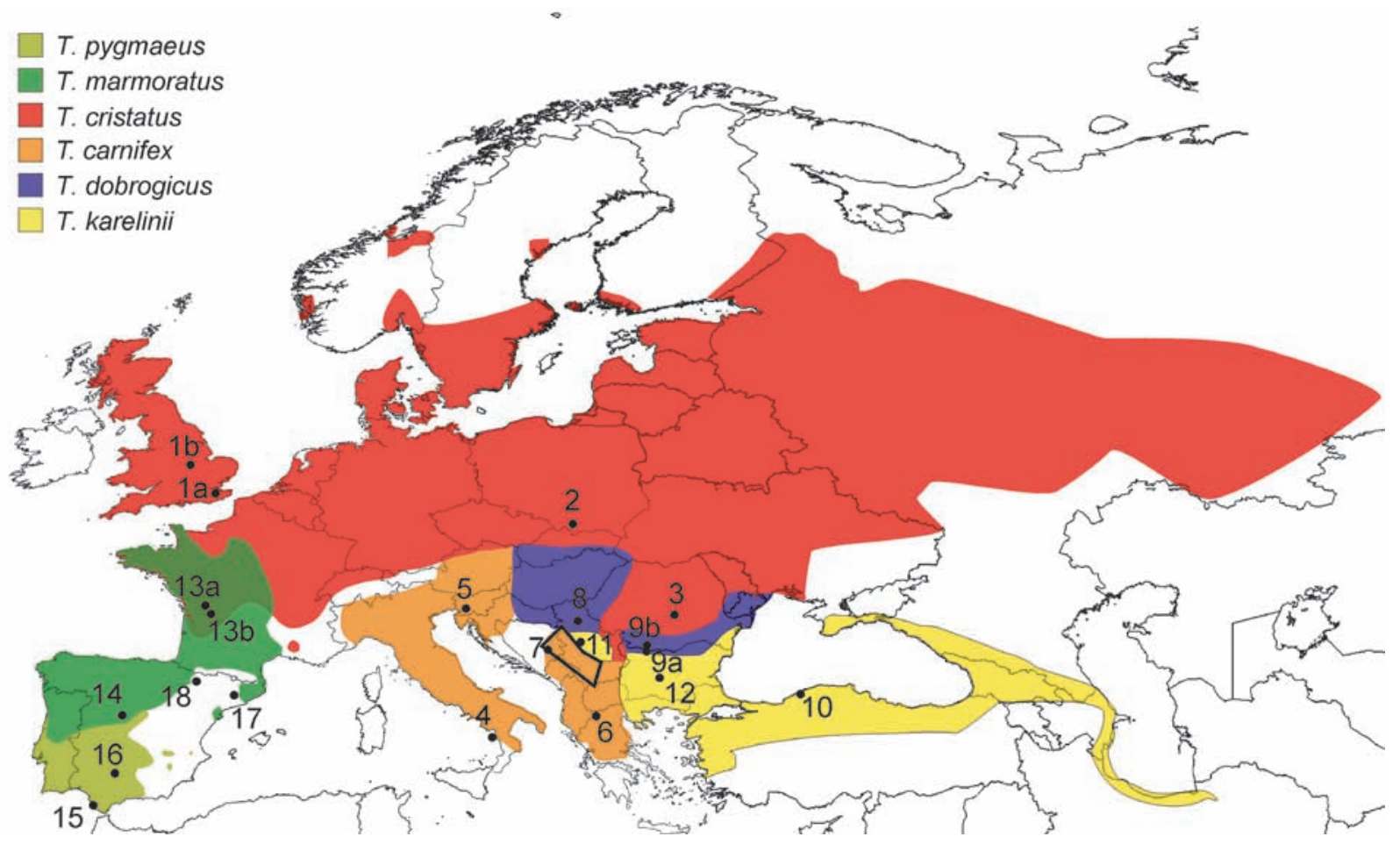

Fig. 1. Approximate geographical distribution of Triturus species, represented by the following colours: orange - T. carnifex, red - T. cristatus, blue - T. dobrogicus, yellow - T. karelinii, dark green - T. marmoratus, light green - T. pygmaeus. Numbers indicate the populations sampled in this study as listed in Appendix I. The concave polygon in the Balkans represents the area where karelinii-type mtDNA was observed in T. carnifex macedonicus (Arntzen and Wallis, 1999 and present study). Note the zone of sympatry between T. cristatus and T. marmoratus in western France. 
The monophyly of the genus Triturus is strongly supported by a number of synapomorphic character states (Arntzen, 2003), including a remarkable genetic condition that kills off all embryos that are homomorphic for either the long or the short copy of chromosome-1, the so-called 'chromosome-1 syndrome' (Ridley, 1993). The small- and medium-sized newt species (alpestris, vittatus, vulgaris and allies), traditionally included in Triturus have recently been placed in genera of their own (García-París et al., 2004; Steinfartz et al., 2007).

Adult crested newts can be organized in a morphological series from a stocky built with well-developed appendages in T. karelinii, to a slender built with short appendages in T. dobrogicus, with T. carnifex and $T$. cristatus taking intermediate positions. This morphocline is expressed in the Wolterstorff Index, which is defined as forelimb length divided by inter-limb distance (Wolterstorff, 1923; Fuhn, 1960; Arntzen and Wallis, 1994). A correlated diagnostic character is the number of rib-bearing vertebrae (NRBV). The NRBV is typically 13 in T. karelinii, 14 in T. carnifex, 15 in $T$. cristatus and 16 or 17 in T. dobrogicus (Arntzen and Wallis, 1999; Arntzen, 2003). In T. marmoratus that is stockier and possesses more developed appendages than either species of crested newt, the NRBV is typically 12 . Taking the marbled newts as an outgroup, the parsimony-based phylogenetic hypothesis for crested newts is (root / T. karelinii (T. carnifex (T. cristatus, $T$. dobrogicus))) with, seen from the root, the first species to split off $T$. karelinii, than T. carnifex and followed by $T$. cristatus and $T$. dobrogicus. We will refer to this topology as the NRBV-constraint.

Newts are aquatic breeders. A relationship has been documented between body shape and the length of time the species annually spends in the water: c. two months for T. marmoratus, three months for T. karelinii, four months for $T$. carnifex, five months for $T$. cristatus and six months for T. dobrogicus. So, the longer the body, the longer the aquatic period (Arntzen, 2003). This suggests that body shape is under selection and raises the possibility that morphology reflects environment instead of phylogeny. Indeed, the phylogenetic hypothesis from the RFLP and sequence analysis of mitochondrial DNA (mtDNA) deviates from the phylogeny suggested by the morphocline (Wallis and Arntzen, 1989; Steinfartz et al., 2007). Twelve tree topologies (enumerated in Table 3) are possible under the assumptions that i) the marbled newts form the sistergroup to the crested newts, i.e., the trees are rooted, and ii) populations and haplotypes fall within the species for which they are recognized. The aforementioned 'NRBV-constraint' equals to tree number 10. In the present study, we set out to elucidate the phylogenetic relationships of the genus Triturus and in particular the Triturus cristatus superspecies. For this purpose, we employ the independent datasets of nuclear encoded protein data and mtDNA-sequence data.

\section{Material and methods}

\section{Sampling strategy}

Adult and juvenile newts were caught by dip netting across Europe and Asiatic Turkey. Individuals were identified to species based on morphology (GarcíaParís et al., 1993; Arntzen and Wallis, 1999). For phylogeny reconstruction, two to four populations per species were selected from a larger sample set, such that 1) identifications are in line with documented geographical distributions, 2) spatial coverage is large, and 3) samples from putative admixture zones are preferably excluded (Fig. 1). Two British (T. cristatus), two French (T. marmoratus) and two neighbouring Dobrogean ( $T$. dobrogicus) populations were pooled. Amplification of DNA from the T. pygmaeus population Venta del Charco was not successful. Sample size ranges from 4 to 20 (average $N=10.0$ ) individuals per population in the protein data set and from 3 to 10 in the mtDNA dataset (average $N=4.6$ ). Following the most recent phylogenetic hypothesis on the Salamandridae (Steinfartz et al., 2007), four specimens of Calotriton asper (Dugès, 1852) from the eastern $(\mathrm{N}=$ $2)$ and western $(\mathrm{N}=2)$ Pyrenean mountains were selected as outgroup to the genus Triturus. Details on localities, sample size and voucher material are presented in Appendix I.

\section{Allozyme data}

Twenty-seven protein systems representing 40 presumptive gene loci were studied by means of starchand polyacrylamide-gel electrophoresis (Table 1). Laboratory protocols and nomenclature of gene products are as in Arntzen (2001). The population genetic parameters evaluated with HP-rare (Kalinowski, 2005) were heterozygosity as expected under conditions of Hardy-Weinberg equilibrium $\left(H_{\mathrm{e}}\right)$, and allelic richness (A) under reference to a sample size of 20 genes. Genetic distances calculated with BIOSYS (Swofford 
Table 1. Allele frequency for 40 presumptive gene loci, surveyed in the Triturus cristatus superspecies and T. marmoratus. Alleles are enumerated alphabetically. Twenty-three different alleles not observed in the present study will be reported elsewhere (J.W. Arntzen, in prep.). To the

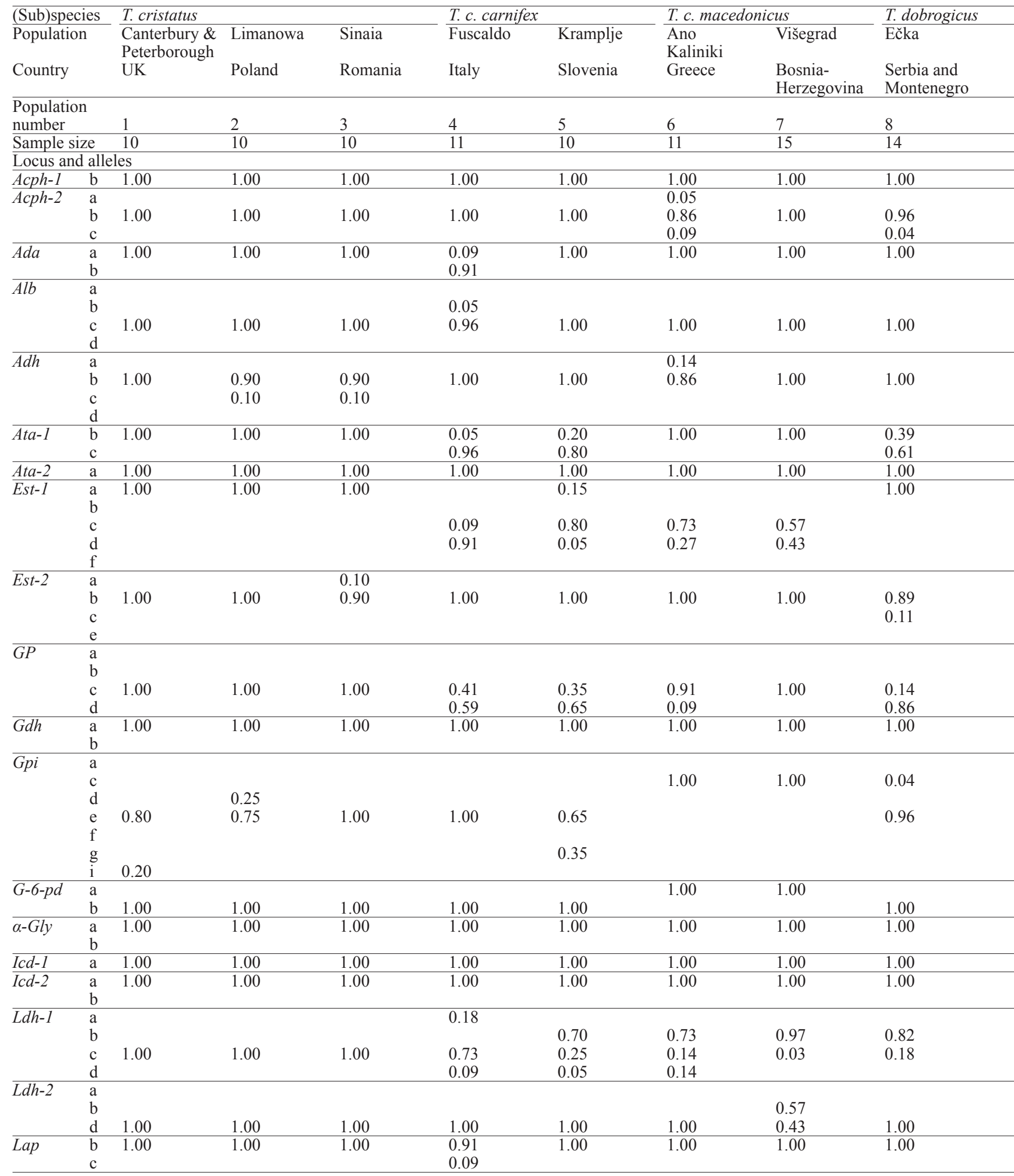


bottom: average allelic richness in reference to a standard population size of 20 genes $(A)$ hierarchical average allelic richness and average heterozygosity under the assumption of Hardy-Weinberg equilibrium $\left(H_{\mathrm{e}}\right)$.

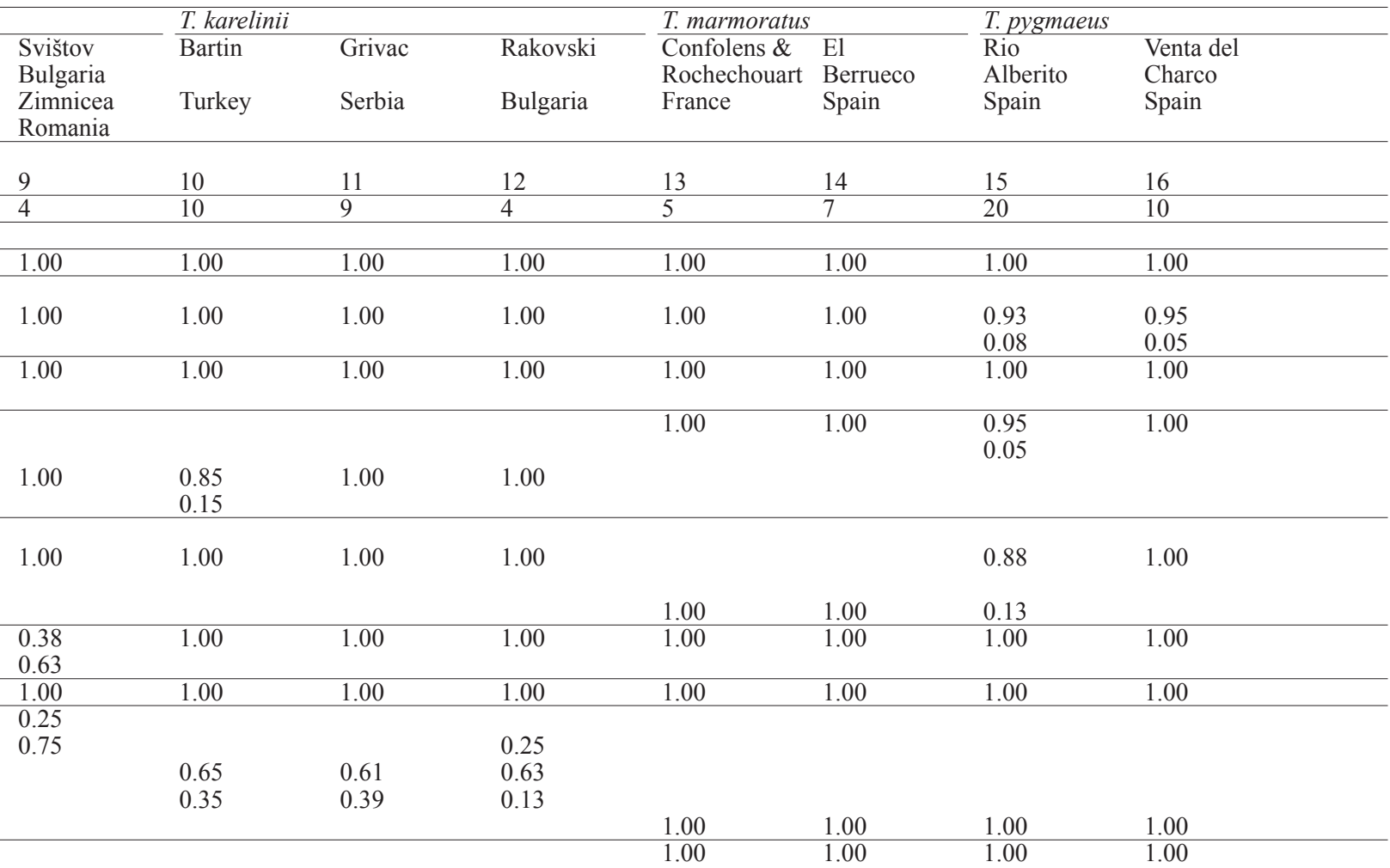

1.00

$1.00 \quad 1.00 \quad 1.00$

$\begin{array}{lll}1.00 & 1.00 & 1.00\end{array}$

\begin{tabular}{|c|c|c|c|c|c|c|c|}
\hline $\begin{array}{l}0.25 \\
0.75\end{array}$ & 1.00 & 1.00 & 1.00 & & & 1.00 & 1.00 \\
\hline 1.00 & $\begin{array}{l}0.95 \\
0.05\end{array}$ & 1.00 & 1.00 & 1.00 & $\begin{array}{l}0.07 \\
0.93 \\
\end{array}$ & 1.00 & 1.00 \\
\hline 0.13 & 0.05 & 0.11 & & & & & \\
\hline 0.88 & 0.90 & 0.89 & 1.00 & 1.00 & 1.00 & 1.00 & 1.00 \\
\hline
\end{tabular}

$\begin{array}{llllllll} & & 0.11 & & & 0.14 & 0.25 & \\ 1.00 & 1.00 & 0.89 & 1.00 & 1.00 & 0.86 & 0.75 & 1.00 \\ 1.00 & 1.00 & 1.00 & 1.00 & & & & \\ & & & & 1.00 & 1.00 & 1.00 & 1.00 \\ 1.00 & 1.00 & 1.00 & 1.00 & 1.00 & 1.00 & 1.00 & 1.00 \\ 1.00 & 1.00 & 1.00 & 0.88 & 1.00 & 1.00 & 1.00 & 1.00 \\ & & & 0.13 & & & & \end{array}$

\begin{tabular}{llllllll}
0.88 & 1.00 & 1.00 & 1.00 & 1.00 & 1.00 & 1.00 \\
& 1.00 & 1.00 & & 1.00 & 1.00 & 1.00 & \\
1.00 & 0.85 & 1.00 & 1.00 & & & & \\
1.00 & 1.00 & 1.00 & 1.00 & 1.00 & 1.00 & 1.00 & 1.00 \\
\hline
\end{tabular}


Table 1. Cont.

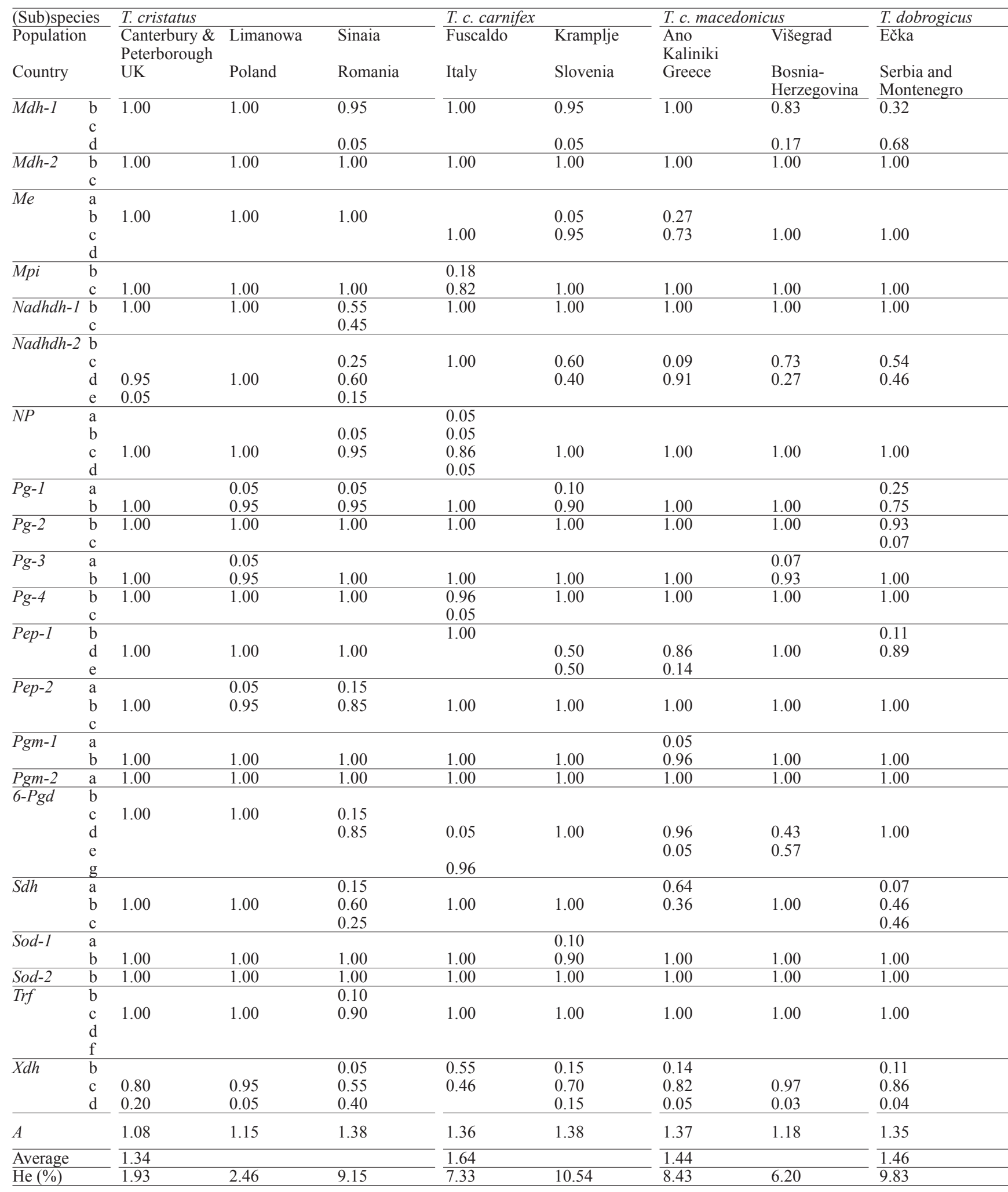




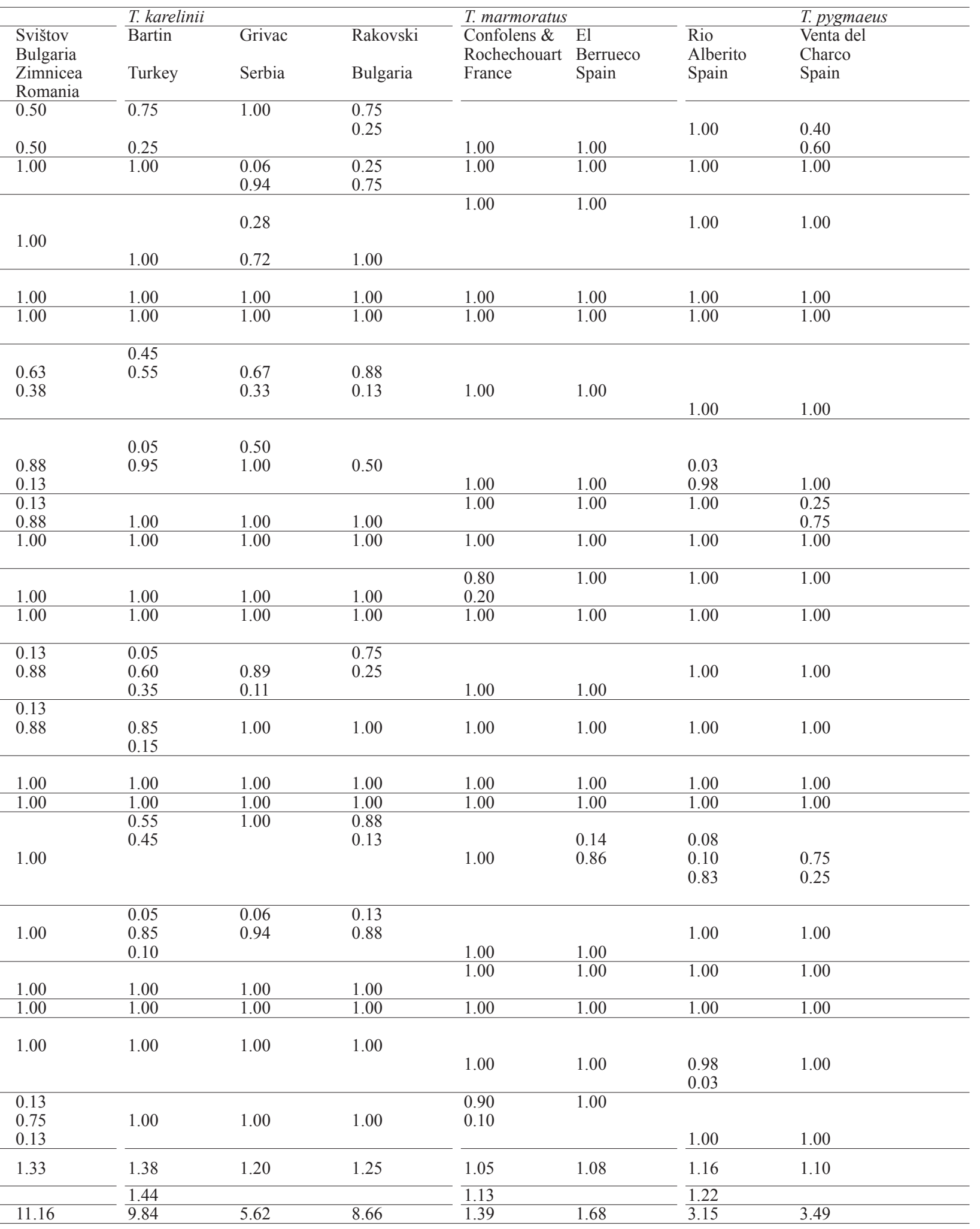


and Selander, 1981) were the Prevosti distance and the Cavalli-Sforza and Edwards chord distance for each locus and Nei's unbiased genetic distance $\left(D_{\mathrm{N}}\right)$ over all loci.

\section{Mitochondrial DNA-sequence data}

Total DNA was extracted from small amounts of newt tissue using the DNeasy Tissue Kit (Qiagen). A segment of subunit 4 of the NADH dehydrogenase mitochondrial gene (ND4) was amplified by polymerase chain reaction (PCR) using the primer ND4 (light chain; 5' -CACCTATGACTACCAAAAGCTCATGTAGAAGC-3'; Arévalo et al., 1994) and the newly designed primers KARF4 (light chain; 5'-AGCGCCTGTCGCCGGGTCAATA-3'), ND4R2 (heavy chain; 5'-CCCTGAAATAAGAGAGGGTTTAA-3'), KARR1 (heavy chain; 5'-AACTCTTCTTGGTGCGTAG-3'), DOBR1 (heavy chain; 5'-GTTTCATAACTCTTCTTGGTGT-3') and DOBR2 (heavy chain; 5'-GTGTTTCATAACTCTTCTTGGT-3').

The polymerase chain reaction (PCR) was conducted in a total volume of $25 \mu \mathrm{L}$, containing $1.0 \mu \mathrm{L}$ of DNA extraction, $2.5 \mu \mathrm{L}$ 10x CoralLoad PCR Buffer (containing $15 \mathrm{mM} \mathrm{MgCl} 2$; Qiagen), $0.8 \mu \mathrm{L}$ of each primer $(10 \mu \mathrm{M}), 1 \mu \mathrm{L}$ dNTPs $(10 \mathrm{mM})$ and $0.2 \mu \mathrm{L}$ of Taq DNA polymerase (5 U/ $\mu \mathrm{L}$; Qiagen), replenished with Milli-Q water. Reaction conditions were: initial denaturation for $3 \mathrm{~min}$ at $94^{\circ} \mathrm{C}$; 35 cycles of $30 \mathrm{sec}$ denaturation at $94^{\circ} \mathrm{C}, 30 \mathrm{sec}$ annealing at $58^{\circ} \mathrm{C}, 1 \mathrm{~min}$ extension at $72^{\circ} \mathrm{C}$; and 4 min final extension at $72^{\circ} \mathrm{C}$. The PCR product was run on $1 \%$ TBE (tris-borateEDTA) agarose gel by electrophoresis, stained with ethidium bromide, and visualised by exposure to UV light in order to check for quality. Negative controls were included to assure that PCR product was not from contaminated sources.

The PCR product was purified using the Wizard SV Gel and PCR Clean-up System (Promega). Cycle sequencing of both the heavy and the light strand was done commercially through Macrogen Inc. The forward and reverse sequences were checked by eye and a consensus sequence was made with Sequencher 4.5 (Gene Codes Corporation). Sequences were aligned manually in MacClade 4.08 (Maddison and Maddison, 2005) and identical sequences were merged into haplotypes. Indications that haplotypes would represent nuclear insertions (i.e., pseudogenes) were not found from either the translated amino-acid sequence (that had no stop codons or inferred insertions/deletions) or nucleotide composition (which was anti G-biased).
The mtDNA dataset contained $642 \mathrm{bp}$, homologous to position 10854-11495 of the mitochondrial genome of Lyciasalamandra atifi (Basoglu, 1967) (Zardoya et al., 2003). To check for the level of substitution saturation, we plotted uncorrected sequence divergence against the Kimura 2-parameter distance $\left(d_{\mathrm{K} 80}\right)$. The relationship was near-linear, suggesting that loss of phylogenetic signal due to multiple hits was not an issue (data not shown). The level of saturation was quantified as 'little' with DAMBE software (Xia and Xie, 2001).

\section{Phylogenetic analysis}

The last four decades have witnessed a plethora of approaches in which allozyme data are employed for phylogeny reconstruction. In order to avoid analytical bias, we followed the recommendations by Wiens (2000) and applied the following methods: maximum parsimony on single-locus Prevosti distances that were coded through step-matrices (MP), phenetic clustering by neighbour-joining on the Cavalli-Sforza and Edwards chord distance (NJ) and continuous maximum likelihood (ML). Tree length comparisons were made under the MP-approach with the Kishino-Hasegawa and Templeton tests in PAUP 4.0* (Swofford, 2003). For reasons of consistency, similar methods were used on the mtDNA-sequences, be it that not populations, but individual haplotypes were involved as Operational Taxonomic Units (OTU). The measure used in the NJ-analysis was the Kimura two-parameter distance. For the likelihood based analyses of DNA-sequence data, we used Modeltest 3.7 (Posada and Crandall, 1998) to determine the best fitting model of sequence evolution as determined by the AIC-criterion. This was the TIM model with a gamma shape parameter of 0.32 , a base composition of $\mathrm{A}=0.30, \mathrm{C}=0.29$ and $\mathrm{G}$ $=0.14$, and the relative rate parameters $1.00,11.56$, $0.36,0.36$ and 6.88 (as in the output format of the program). The software programmes used for phylogenetic analysis were PHYLIP 3.573c (Felsenstein, 1993) and PAUP 4.0* (Swofford, 2003). To evaluate the strength of support by the underlying data to branches in the phylogenetic tree, we ran 2000 bootstrap replications for each of the three approaches. Bootstrap replication scores (brs) of $>0.80$ were interpreted as strong support, $0.70 \leq$ brs $\leq 0.80$ were interpreted as moderate support of the data to the phylogenetic tree. Additionally, the mtDNA data were analyzed under Bayesian inference with MrBayes 3.1 (Ronquist and Huelsenbeck, 2003). This involved the running of four Metropolis Coupled Monte Carlo Markov Chains 
Fig. 2. Hypothetical phylogeny for the genus Triturus. Branches are numbered as in Table 2.

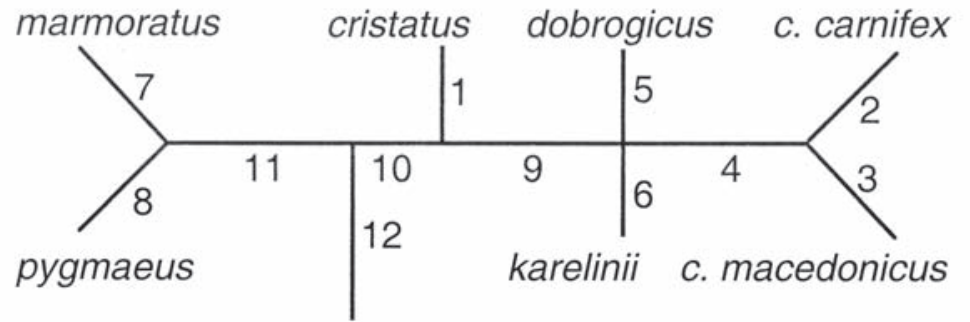

outgroup / Calotriton asper
(MCMC), one cold and three incrementally heated, starting from a random topology. Two separate runs of two million generations were conducted simultaneously and for each run, the cold chain was sampled every 1000 generations under the best-fit model of molecular evolution $(\mathrm{HKY}+\mathrm{G})$ selected with MrModelTest (Nylander, 2004). The software Tracer 1.3 (Rambaut and Drummond, 2004) was used to check for stabilization of overall likelihood within and convergence between runs. The first $10 \%$ of sampled trees was discarded as burn-in and the inference was drawn from the remaining pooled sample. Bayesian posterior probabilities (pp) of $>0.95$ were interpreted as strong support and $0.90 \leq \mathrm{pp} \leq 95$ were interpreted as moderate support of the data to the tree.

We used linear interpolation from a set calibration point to estimate the divergence times for major clades. With the same aim, 2000 Bayesian trees from two runs and a $50 \%$ 'burn-in' were analyzed with the software r8s (Sanderson, 2004), to reconstruct divergence times under the assumption of a molecular clock using the LF maximum likelihood method and the TN algorithm (see r8s manual). This yielded the most likely estimates (mean and mode) and the $95 \%$ confidence interval of the mean.

\section{Results}

\section{Allozymes}

The allelic richness averaged over 40 enzyme loci ranged from low values in T. marmoratus and T. pygmaeus $(A=1.13-1.22)$, medium values in $T$. cristatus, T. dobrogicus, T. c. macedonicus and T. karelinii $(A=$ $1.34-1.44)$, to a relatively high value in $T$. c. carnifex $(A=1.64)$. Triturus $c$. macedonicus and $T$. cristatus stand out from the other (sub)species by the marked difference between populations, with low values observed in Višegrad and the UK and Poland, respective- ly (Table 1). Within T. cristatus the spatial distribution of allozyme genetic variation is in line with a postglacial dispersal scenario from the southern Carpathians all over northern Europe, supporting similar data from RFLP- and MHC-based molecular analyses (Wallis and Arntzen, 1989; W. Babik, personal communication). Average expected heterozygosity and AR are correlated across populations $\left(\mathrm{r}_{\text {Spearman }}=0.88\right.$, Table 1$)$.

Maximum parsimony analysis of the allozyme data yielded moderate or strong support for the grouping of populations within (sub)species for T. c. macedonicus, T. dobrogicus, T. karelinii and T. marmoratus (Figure 2, Table 2). Neighbour-joining and maximum likelihood analysis showed moderate or strong support for all taxa within Triturus with the exception of T. c. carnifex and T. carnifex. The grouping together of all crested newt taxa was supported throughout, while moderate support (brs $=0.71)$ for a sister group position of $T$. cristatus to the other crested newt species was obtained with maximum parsimony analysis only. The MP-tree obtained under the NRBV-constraint was $4.5 \%$ longer than the most parsimonious solution. The difference in tree length is marginally significant under the KishinoHasegawa test $(\mathrm{P} \approx 0.05)$ and significant under the Wilcoxon signed-ranks tests $(\mathrm{P}<0.05)$. Under the prerequisite that populations fall within the species for which they are recognized, tree number 2: (root /T . cristatus (T. dobrogicus (T. carnifex, T. karelinii))) is the most parsimonious and only tree number 4: (root / T. carnifex (T. cristatus (T. dobrogicus, T. karelinii))) is significantly longer than this best tree (Table 3 ).

Genetic distances ranged from $D_{\mathrm{N}}=0.001$ among populations of $T$. marmoratus and $D_{\mathrm{N}} \approx 0.035$ among populations of $T$. karelinii and T. pygmaeus, to $D_{\mathrm{N}}=$ 0.11 among populations of $T$. c. carnifex (Table 2). The maximum observed genetic distance within a species was $D_{\mathrm{N}}=0.25$ between $T$. c. carnifex from Fuscaldo, Italy and T. c. macedonicus from Ano Kaliniki, Greece. This single value exceeded the average value among crested newt species $\left(D_{\mathrm{N}}=0.19\right)$ and among marbled 
Table 2. Left panel. Bootstrap replication scores (brs) and Bayesian posterior probabilities (pp) for branches in the phylogenetic tree of the genus Triturus as estimated under maximum parsimony (MP), neighbour-joining (NJ), maximum likelihood (ML) and Bayesian (B) methods of inference for allozyme data (top panel) and for mtDNA-sequence data (lower panel). Clades with consistently low statistical support are collapsed (bootstrap replication score (brs) not exceeding 0.70 or posterior probability (pp) not exceeding 0.90 ). The remaining branches are numbered as in Figure 2. Internal interspecific branches are shown in boldface type. Right panel: observed maximum and hierarchical averages of genetic distances and divergence times between species and subspecies estimated from an external calibration point at $24 \mathrm{Ma}$ (Steinfartz et al., 2007) by linear interpolation and with the software r8s (Sanderson, 2004; details see text). The calibration point refers to the crown node of branch 12 and represents the most recent common ancestor (MRCA) of all Triturus species.

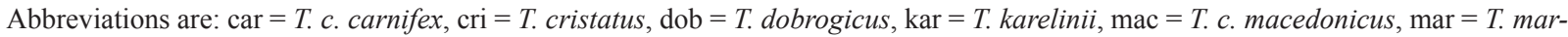
moratus, pyg $=$ T. pygmaeus, n.a. $=$ not applicable and CI is $95 \%$ confidencce interval.

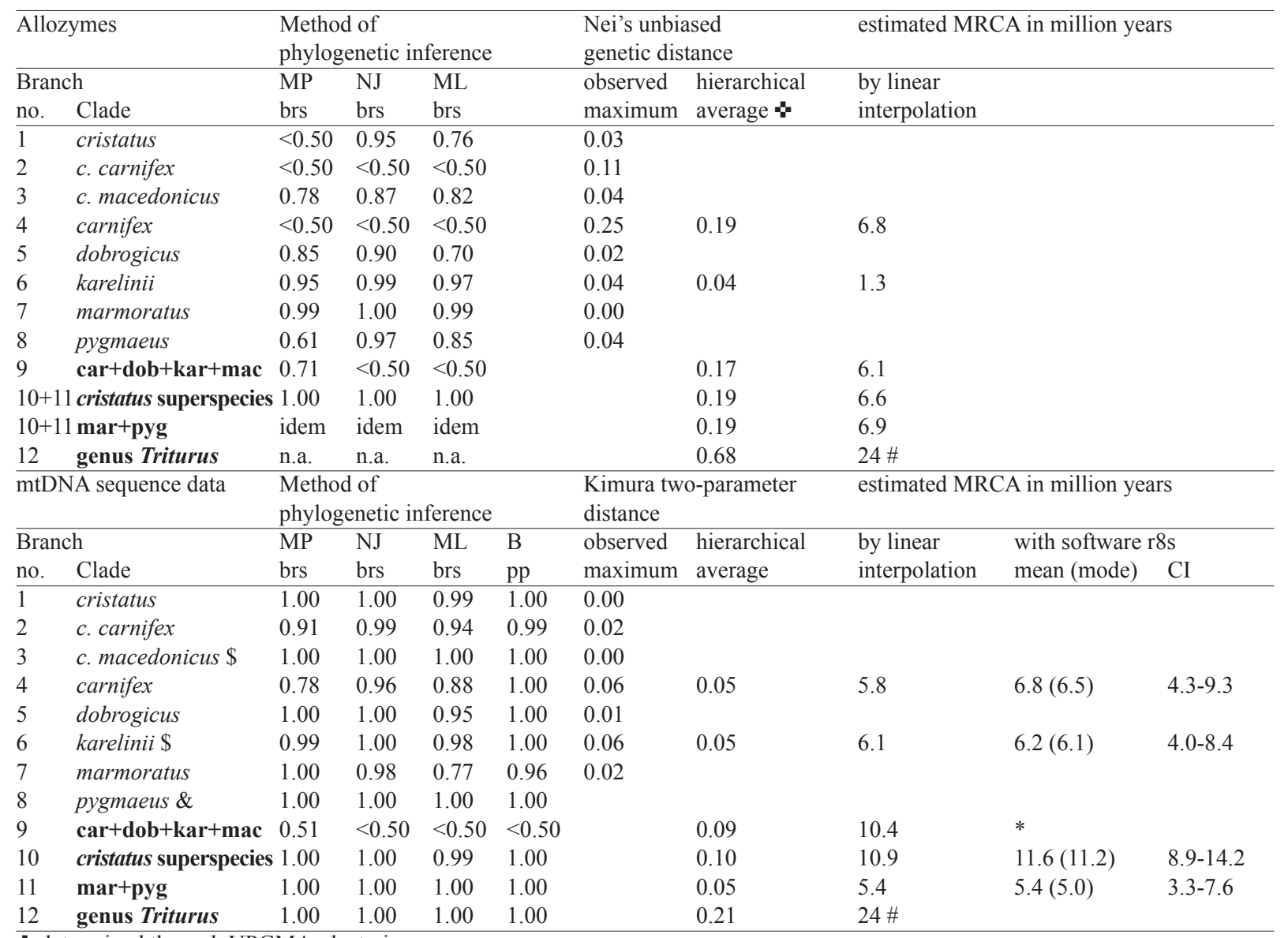

+ determined through UPGMA-clustering.

\# calibration point following Steinfartz et al., 2007.

\$ haplotypes from the Višegrad population included with $T$. karelinii.

$\&$ represented by one haplotype

* tree not supported.

newt $\left(D_{\mathrm{N}}=0.19\right)$ species. The crested newt and marbled newt species groups showed genetic differentiation at the level of $D_{\mathrm{N}}=0.68$. Linear interpolation of the pairwise genetic distances against a calibration point of $24 \mathrm{Ma}$ (million years before present) for the most recent common ancestor (MRCA) of T. cristatus - T. marmoratus (Steinfartz et al., 2007) yielded estimates in the range of 7-6 Ma for the age of each of the six Triturus species and an estimate of 1.3 Ma for the Asian versus European populations of T. karelinii (Table 2).

\section{Mitochondrial DNA-sequences}

Fifteen different haplotypes were identified among the 
Table 3. Difference in tree length between the phylogeny showing maximum parsimony and 11 alternative topologies for the Triturus cristatus superspecies, for respectively allozyme and mtDNA-sequence data, tested with the Kishino-Hasegawa and Templeton tests (* - P $<0.05$, and NS - not significant). The twelve topologies are constructed under the proviso that the marbled newts are the sister group to the crested newts and that OTU's (i.e., populations, respectively haplotypes) fall within the species for which they are recognized. Note however that karelinii-like haplotypes observed in Triturus carnifex macedonicus from Višegrad were legitimately included with T. karelinii (for details see text).

\begin{tabular}{|c|c|c|c|c|c|c|}
\hline Tree & Species spli & off as seen from the root & Allozymes & & mtDNA sequences & \\
\hline no. & first & second & Kishino-Hasegawa & Templeton & Kishino-Hasegawa & Templeton \\
\hline$\overline{1}$ & cristatus & carnifex & $\mathrm{NS}$ & NS & best tree & best tree \\
\hline 2 & & dobrogicus & best tree & best tree & NS & NS \\
\hline 3 & & karelinii & NS & NS & * & NS \\
\hline 4 & carnifex & cristatus & * & * & NS & NS \\
\hline 5 & & dobrogicus & NS & NS & * & NS \\
\hline 6 & & karelinii & NS & NS & NS & NS \\
\hline 7 & dobrogicus & carnifex & NS & NS & NS & NS \\
\hline 8 & & cristatus & NS & NS & NS & NS \\
\hline 9 & & karelinii & NS & NS & NS & NS \\
\hline $10 \#$ & karelinii \$ & carnifex & NS & NS & NS & NS \\
\hline 11 & & cristatus & NS & NS & * & * \\
\hline 12 & & dobrogicus & NS & NS & NS & NS \\
\hline
\end{tabular}

\# equivalent to NRBV-constraint (see text).

\$ two mtDNA haplotypes from the Višegrad population included with T. karelinii.

crested newt mtDNA-sequences, four different haplotypes were found for the marbled newts and three for Calotriton asper (Appendix II). The maximum observed sequence divergence ranged from $d_{\mathrm{K} 80}=0$ (haplotypes identical) in T. pygmaeus, $d_{\mathrm{K} 80} \approx 0$ in $T$. cristatus and T. c. macedonicus, $d_{\mathrm{K} 80} \approx 0.01$ in $T$. dobrogicus, $d_{\mathrm{K} 80} \approx 0.02$ in T. c. carnifex and T. marmoratus to $d_{\mathrm{K} 80} \approx 0.06$ in T. carnifex and T. karelinii (Table 2). Interspecific comparisons yielded mean values of $d_{\mathrm{K} 80} \approx 0.05$ among the marbled newts, $d_{\mathrm{K} 80} \approx 0.10$ among crested newts and $d_{\mathrm{K} 80}=0.21$ between marbled and crested newts. The mtDNA-sequence data also indicate a marked substructuring within $T$. karelinii, between the Asian (haplotypes h11-h13) and European populations (haplotypes h14 and h15) at the level of $d_{\mathrm{K} 80}=0.053$.

One hundred and ninety two nucleotide positions $(29.9 \%)$ were variable and $178(27.7 \%)$ parsimony informative at the level of the genus Triturus and 133 nucleotide positions $(20.7 \%)$ were variable and 120 $(18.7 \%)$ parsimony informative at the level of the $T$. cristatus superspecies. The four methods of phylogenetic inference (MP, NJ, ML and Bayesian) applied to the unique haplotypes yielded essentially equivalent results. This included, at best, weak support for a position of $T$. cristatus as sister-group to the other crested newt species (Table 2). A discrepancy was observed between signals from the nuclear and mito- chondrial markers in the position of the population from Višegrad. This population classifies on the basis of allozymes as T. c. macedonicus whereas the mitochondrial haplotype that it carries is typical for $T$. karelinii (Figure 3). This situation was discovered for several populations in northern Serbia before (Wallis and Arntzen, 1989; Arntzen and Wallis, 1999).

The MP-tree obtained under the NRBV-constraint was $1.0 \%$ longer than the most parsimonious solution. The difference in tree length is not significant under the Kishino-Hasegawa and the Wilcoxon signed-ranks tests $(\mathrm{P}>0.05)$. Under the prerequisite that haplotypes fall within the species for which they are recognized (with the exception of haplotypes from Višegrad), the favoured tree was number 1: (root / T. cristatus (T. carnifex (T. dobrogicus, T. karelinii))). Trees 3, 4, 5 and 11 are statistically less parsimonious than this best tree, depending on the testing procedure (Table 3 ).

Interpolation of the $d_{\mathrm{K} 80}$ distances against the 24 Ma calibration point for the most recent common ancestor of T. cristatus - T. marmoratus yielded estimates in the range of c. $11 \mathrm{Ma}$ for the radiation of the Triturus cristatus superspecies, c. 6 Ma for the MRCA of T. c. carnifex and T. c. macedonicus and for the Asian versus European populations of T. karelinii and c. 5 Ma for the split between T. marmoratus and $T$. pygmaeus (Table 2). 

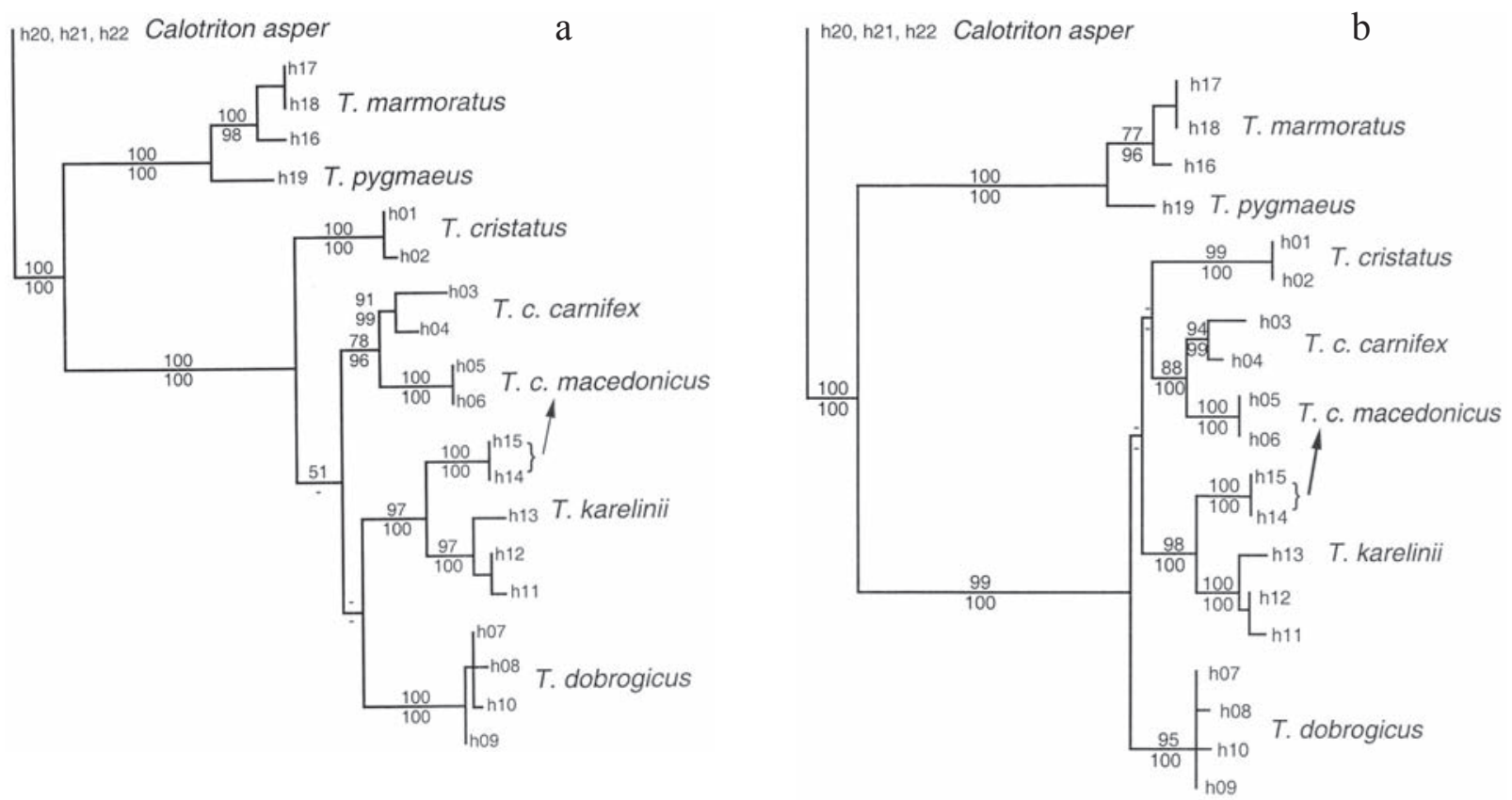

Fig. 3. Phylogenetic trees for the genus Triturus on the basis of ND4 mtDNA haplotypes (h01-h19), with Calotriton asper (h20-h22) as outgroup, with the preferred solution under (a) maximum parsimony and (b) maximum likelihood. Haplotype numbers are as presented in Appendix II. Values over branches are percent bootstrap replications scores for maximum parsimony and maximum likelihood (above branches) and neighbour-joining and Bayesian posterior probabilities (below branches). Values $<50$ are indicated by a hyphen (-). Note that four individuals of T. carnifex macedonicus from Višegrad carry haplotypes h14 or h15, which are otherwise characteristic of $T$. karelinii.

\section{Discussion}

Genetic coherence of species and subspecies

The monophyly of the Triturus cristatus superspecies and its sister-group relationship to the marbled newts are unambiguously supported by mtDNA and allozymes, through outgroup rooting and midpoint rooting, respectively. The two data sets generally agree with one another and with current taxonomy, in the recognition of two species of marbled newts, four species of crested newts plus the subspecies T. c. macedonicus. However, the allozyme data are less explicit than the mtDNA-sequence data and do not provide strong support for the monophyly of T. carnifex and its subspecies T. c. carnifex (all three methods of phylogenetic inference; see also Arntzen, 2001), nor for the genetic coherence of T. cristatus and T. pygmaeus under maximum parsimony (Table 2). Also the subdivision of $T$. karelinii over two European and one Asian populations is stronger supported by mtDNA data than with allozymes. Conversely, the Višegrad population, which belongs to T. c. macedonicus on the basis of external morphology, NRBV and allozymes, would erroneously be classified as $T$. karelinii on the basis of mtDNA. The extensive asymmetric introgression of mtDNA across species boundaries has been reported manifold. An extreme case is documented for the newt Lissotriton montandoni (Boulenger, 1880). This species has turned 'invisible' from the mitochondrial perspective, due to the complete replacement of indigenous mtDNA by that of L. vulgaris (Linnaeus, 1758) (Babik et al., 2005). In order to compare patterns of introgression between nuclear and mtDNA markers and to distinguish between recent introgression and ancients polymorphisms cq. incomplete lineage sorting, it would be required to conduct a wider spatial survey with populations at various distances to species borders (J.W. Arntzen, in prep.).

\section{Phylogeny}

We gathered data from 40 allozyme loci and DNA-sequence information from a stretch of a rapidly evolv- 
ing protein coding mitochondrial gene (ND4) to reconstruct the evolutionary history of the T. cristatus superspecies, employing a cross-section of phylogenetic methodologies (MP, NJ, ML and Bayesian). However, neither the allozyme nor the mtDNA data resolve the phylogeny of crested newts at the species level. The preferred topologies are diverse and have in common that internal branches at the species level gain low statistical support (Table 2, Fig. 3). The absence of phylogenetic resolution can not be attributed to either too high or too low a level of genetic differentiation at the average enzyme locus (see Table 1 and genetic distance information in Table 2). Also, homoplasy in the DNA-sequences is not a major issue (see results). Both data sets contradict the NRBV-based phylogenetic hypothesis and because of the correlation between NRBV character-states and the ecology of the species (in terms of the general slender-stout morphological series and the length of the annual aquatic phase) we suggest that NRBV is under natural selection and, hence, not an informative character for building a phylogeny. In the absence of phylogenetic resolution, we suggest that the polytomy recovered in the crested newts is 'hard' and that the suggested simultaneous origin of four lineages reflects reality (Whitfield and Lockhart, 2007). However, 'absence of proof' shall not be confused with 'proof of absence'. In other words, this hard polytomy constitutes a hypothesis that may be falsified, e.g., through the sequencing of the full mitochondrial DNA genome (c. 16,000 bp) and the sequencing of nuclear genes.

\section{Historical biogeography}

The Balkan Peninsula, where the four species of crested newts meet (Fig. 1), has been recognized as the centre of origin of crested newt diversity (Crnobrnja-Isailović et al., 1997). Our data support this interpretation, to which we add that the different species have arisen in close temporal proximity. Whether the evolutionary split of one into four lineages was truly simultaneous (i.e., a 'hard' polytomy with branch lengths of zero in the phylogenetic tree) or a nearsimultaneous 'soft' polytomy (with small but non-zero branch lengths in a topology that is currently unresolved) is immaterial for the purpose of our biogeographical analysis, given the rough resolution - in terms of both time and space - provided by the available paleogeographical reconstructions (see below).

A temporal calibration of divergence times within the Salamandridae was provided by Steinfartz et al.
(2007), who used a fossil-based molecular dating approach, cross-validated with palaeogeographical data for the Holarctic region. The MRCA of the crested and marbled newts was dated at $24 \mathrm{Ma}$. Accordingly, we estimate the radiation of the proto-crested newt into four lineages (corresponding with the four species) by linear interpolation separately for the allozyme data and for the mtDNA-sequence data. This yields, however, two different solutions (Table 2) and the discrepancy is reflected in different biogeographical reconstructions (scenarios 1 and 2 below). Popov et al. (2004) present a series of ten paleogeographic maps for southeastern Europe that cover the period from $37 \mathrm{Ma}$ to the present. Schematic versions of map 6 of the Mid Middle Miocene at 14-13 Ma, map 7 of the Late Middle Miocene at 12-11 Ma and map 8 of the Mid Late Miocene at 8.5-7 Ma are shown in Figure 4.

Scenario 1 - allozymes. Following the allozyme molecular clock, the as yet undifferentiated protocrested newt would be positioned on the central Balkan Peninsula in the Late Miocene. At 8.5-7 Ma a solid, unfragmented landmass encircled the Pannonian Basin and Europe and Asia were not disconnected (Figure 4c). This allows for the spread of crested newts over the region, as was proposed by CrnobrnjaIsailović et al. (1997: Figure 2). From one central stock positioned at approximately the present day city of Sofia, the crested newts dispersed in four compass directions: the lineage to the east gave rise to T. dobrogicus, the lineage to the south gave rise to T. karelinii, the lineage to the west dispersed along the Dinarides and formed T. carnifex and one lineage dispersed northwards along the Carpathians and formed T. cristatus. However, no vicariant events were postulated that would promote speciation through genetic differentiation in allopatry. Indeed, no vicariant events potentially associated with cladogenetic events are apparent for the region from the paleogeography of southeastern Europe over the period 6.1 Ma to $1.8 \mathrm{Ma}$ (Popov et al., 2004: maps 9 and 10).

Scenario 2 - mitochondrial DNA. According to the mitochondrial DNA molecular clock, one would place the as yet undifferentiated proto-crested newt in the central Balkan Peninsula in the Middle Miocene. At 14-13 Ma the area was covered by a presumably continuous landmass encircling the Pannonian Basin. Turkey and Europe were connected (Figure 4a). In particular, Dobrogea was not yet an island. During this époque, no major barriers would seem to hamper the spread of the species over the area. Two million years on (12-11 Ma, Figure 4b), the different areas keeping 


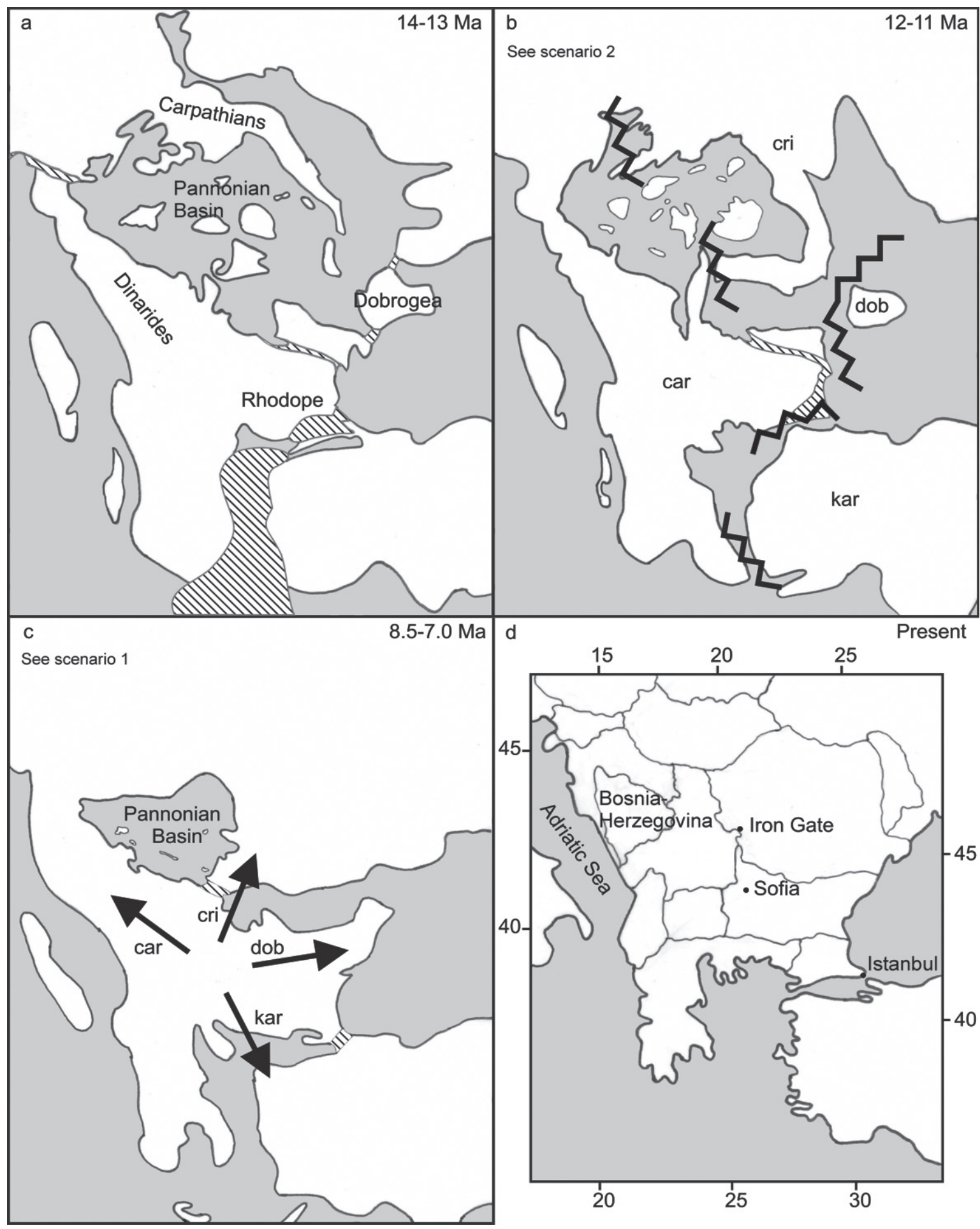

Fig. 4. Paleogeographical reconstruction of south-eastern Europe according to Popov et al. (2004), with land-masses unshaded and seas shaded. Question marks in the original publication are represented by hatching. (a) Situation in the Mid Middle Miocene (14-13 Ma), (b) situation in the Late Middle Miocene (12-11 Ma), with biogeographical hypothesis according to scenario 2, (c) Mid Late Miocene (8.57.0 Ma) with biogeographical hypothesis according to Crnobrnja-Isailović et al. (1997) (scenario 1), and (d) present day. Abbreviations are as in Table 2. Proposed vicariant effects are shown by zig-zag lines. 
the four species in statu nascendi became disconnected. The isolation was most pronounced for Dobrogea that harboured the T. dobrogicus lineage. Interestingly, T. dobrogicus is the first species to arise in the maximum likelihood and Bayesian analysis of the mtDNA data, be it with low statistical support (Figure 3b). The Carpathians were disconnected from the mountains on the Balkans (Dinarides, Rhodope) by a sea-straight in position of the present day Iron Gate. This sea-strait separated the T. cristatus and T. carnifex lineages and a sea-strait between Europe and Asia separated the $T$. karelinii lineage (Fig. 4b). At 8.5-7.0 Ma Dobrogea became reconnected to the continent and the sea-straits at the Iron Gate and north of present day Istanbul may have closed (Fig. 4c). This brought the four species back into contact and allows for the relatively small interspecific range adjustments that are required to explain the present day distribution. Scenario 2 supports the near-synchronous crested newt radiation dated at either c. $13.5 \mathrm{Ma}$ (paleographic data) or c. $11 \mathrm{Ma}$ (molecular data).

It invokes vicariant effects brought about by major changes in the land-water distribution over the area. The scenario also allows for a long period - between 14-13 Ma and 8.5-7 Ma - over which the four lineages started their independent evolutionary routes and acquired a large degree of reproductive isolation. To position the crested newt radiation at precisely $10.9 \mathrm{Ma}$ (Table 2, Fig. 4b) would require extensive dispersal including the crossing of sea-straits to reach the various landmasses that - on the basis of the current distribution of crested newts - would logically be associated with the four species (Fig. 4b). Amphibians however have generally poor dispersal capabilities and their propensity to cross major barriers such as sea-straits is small. Indeed, present day sea straights such as the Bosporus and the Straights of Dover and Gibraltar are effective barriers to dispersal (Beerli et al., 1996; Veith et al., 2004; Recuero et al., 2007).

We prefer scenario 2 over scenario 1 . Scenario 2 is detailed and explicit. It naturally suggests the nearsimultaneous origin of the four species comprising the crested newt superspecies. Moreover, scenario 2 involves only a small discrepancy in the exact timing of the radiation as c. $11 \mathrm{Ma}$ from molecular data versus $>$ 12-11 Ma (Fig. 4b) and < 14-13 Ma (Fig. 4a) from paleogeographic data. By consequence, we prefer the mtDNA calibration of the molecular clock over the allozyme calibration. This calibration dates the origin of T. c. carnifex of the Apennine Peninsula and T. c. macedonicus of the Balkan Peninsula at 5.8 Ma. These two subspecies are allopatric, separated from one another by the karst region of Bosnia-Herzegovina. The date approximately coincides with the filling of the Mediterranean that followed the Messinian Event at $5.3 \mathrm{Ma}$ (Krijgsman et al., 1999). So, here we invoke yet another vicariance effect to explain the evolutionary history of the genus Triturus and suggest that $T$. c. carnifex and T. c. macedonicus started to diverge following the origin of the Adriatic Sea.

\section{Taxonomic considerations}

Handbooks of the past century either position a parapatric range border between $T$. carnifex and T. karelinii in the northern Balkans (Thorn, 1968), or place their range border at the Bosporus (Steward, 1969). It was not recognized that the large central part of the peninsula, approximately coinciding with Bosnia-Herzegovina, is devoid of Triturus newts. Arntzen and Wallis (1999) documented the eastern range limit of $T$. carnifex as running between Croatia and BosniaHerzegovina. They resurrected the taxon Triturus $c$. macedonicus (with a distribution over the Balkans south and east of Bosnia-Herzegovina, Fig. 1) that was originally described as Molge karelinii var. macedoni$c a$ by S. Karaman in 1922. The subspecies was classified as T. carnifex (and not T. karelinii) on the basis of NRBV and mtDNA RFLP analysis (Arntzen and Wallis, 1999) and our new sequence data support this interpretation. We observed a high level of genetic differentiation between T. c. macedonicus and the nominotypical subspecies $\left(D_{\mathrm{N}}=0.192, d_{\mathrm{K} 80}=0.051\right)$, paralleling RFLP data (Wallis and Arntzen, 1989; Faith and Cranston, 1991). Morphologically the taxa are distinguishable in colouration and spotting pattern (Arntzen and Wallis, 1999; Arntzen, 2003: 459). This raises the question whether T. c. macedonicus had better be considered a species. Unfortunately, the biological species concept cannot be made operational due to the subspecies' allopatry. In the absence of a direct test we use an indirect line of reasoning. Firstly, the genetic differentiation between $T$. c. carnifex and T. c. macedonicus is comparable to that of T. marmoratus and $T$. pygmaeus (Table 2), two former subspecies for which species status has recently been corroborated (Espregueira Themudo and Arntzen, 2007). Secondly, the forms are old (we estimate $>5 \mathrm{Ma}$ ) and may have followed independent evolutionary pathways ever since. We therefore elevate the taxonomic status of T. c. macedonicus to that of the species, i.e., Triturus macedonicus (Karaman, 1922). 


\section{Acknowledgements}

We thank S. Carranza (Barcelona, Spain) for tissue material of Calotriton asper.

\section{References}

Arévalo E, Davis SK, Sites JW Jr. 1994. Mitochondrial DNAsequence divergence and phylogenetic relationships among eight chromosome races of the Sceloporus grammicus complex (Phrynosomatidae) in Central Mexico. Systematic Biology 43: 387-418.

Arntzen JW, Wallis GP. 1994. The 'Wolterstorff Index' and its value to the taxonomy of the Crested Newt superspecies. Abhandlungen und Berichte für Naturkunde 17: 57-66.

Arntzen JW, Wallis GP. 1999. Geographic variation and taxonomy of crested newts (Triturus cristatus superspecies): morphological and mitochondrial DNA data. Contributions to Zoology 68: 181-203.

Arntzen JW. 2001. Genetic variation in the Italian crested newt, Triturus carnifex, and the origin of a non-native population north of the Alps. Biodiversity and Conservation 10: 971987.

Arntzen, JW. 2003. Triturus cristatus Superspezies - KammolchArtenkreis (Triturus cristatus (Laurenti, 1768) - Nördlicher Kammolch, Triturus carnifex (Laurenti, 1768) - Italienischer Kammolch, Triturus dobrogicus (Kiritzescu, 1903) - DonauKammolch, Triturus karelinii (Strauch, 1870) - Südlicher Kammolch). Pp. 421-514 in: K. Grossenbacher and B. Thiesmeier (eds), Handbuch der Reptilien und Amphibien Europas - Band 4/IIA: Schwanzlurche (Urodela) IIA. AULA-Verlag, Wiebelsheim.

Beerli P, Hotz H, Uzzell T. 1996. Geologically dated sea barriers calibrate a protein clock for aegean water frogs. Evolution 50: 1676-1687.

Bolkay SJ. 1928. Die Schädel der Salamandrinen, mit besonderer Berücksichtigung auf ihre systematische Bedeutung. Zeitschrift für Anatomie und Entwicklungsgeschichte 86: 256-319.

Crnobrnja-Isailović J, Džukić G, Krstić N, Kalezić ML. 1997. Evolutionary and paleogeographical effects on the distribution of the Triturus cristatus superspecies in the central Balkans. Amphibia-Reptilia 18: 321-332.

Espregueira Themudo G, Arntzen JW. 2007. Molecular identification of marbled newts and a justification of species status for Triturus marmoratus and T. pygmaeus. Herpetological Journal 17: 24-30.

Faith, DP, Cranston PS. 1991. Could a cladogram this short have arisen by chance alone ? On permutation tests for cladistic structure. Cladistics 7: 1-28.

Felsenstein, J. 1993. PHYLIP 3.573c. Computer program for inferring phylogenies, distributed by the author at http://evolution.gs.Washington.edu/phylip.html.

Fuhn, IE. 1960. Amphibia. Fauna Republicii Populare Romine, Vol. XIV part 1. Academiei R. P. Romĭne, Bucuresti.

García-París M, Herrero P, Martín C, Dorda J, Esteban M, Arano B. 1993. Morphological characterization, cytogenetic analy- sis, and geographical distribution of the Pygmy marbled newt Triturus marmoratus pygmaeus (Wolterstorff, 1905) (Caudata: Salamandridae). Contributions to Zoology 63: 3-14.

García-París M, Montori A, Herrero P. 2004. Amphibia: Lissamphibia. Fauna Iberica Vol. 24. Museo Nacional de Ciencias Naturales and Consejo Superior de Investigaciones Científicas, Madrid.

Gvozdik L, van Damme R. 2006. Triturus newts defy the running-swimming dilemma. Evolution 60: 2110-2121.

Harvey PH, Pagel MD. 1991. The comparative method in evolutionary biology. Oxford University Press, Oxford.

Ivanović A, Vukov TD, Džukić G, Tomašević N, Kalezić ML. 2007. Ontogeny of skull size and shape changes within a framework of biphasis lifestyle: a case study in six Triturus species (Amphibia, Salamandridae). Zoomorphology 126: 173-183.

Kalinowski ST. 2005. HP-rare: a computer program for performing rarefaction on measures of allelic diversity. Molecular Ecology Notes 5: 187-189.

Krijgsman W, Hilgen FJ, Raffi I, Sierro FJ, Wilson DS. 1999. Chronology, causes and progression of the Messinian salinity crisis. Nature 400: 652-655.

Maddison DR, Maddison WP. 2005. MacClade 4: analysis of phylogeny and character evolution, version 4.08. Sinauer Associates, Sunderland, Massachusetts.

Nylander JAA. 2004. MrModeltest 2. Program distributed by the author. Evolutionary Biology Centre, Uppsala University.

Popov SV, Rögl F, Rozanov AY, Steiniger FF, Shcherba IG, Kovac M (eds). 2004. Lithological-Paleogeographic maps of Paratethys: 10 maps Late Eocene to Pliocene. Courier Forschungsinstitut Senckenberg 250: 1-46.

Posada D, Crandall KA. 1998. Modeltest: testing the model of DNA substitution. Bioinformatics 14: 817-818.

Rambaut A, Drummond AJ. 2004. Tracer 1.3, Available from http://beast.bio.ed.ac.uk/Tracer.

Recuero E, Iraola A, Rubio X, Machordom A, García-París M. 2007. Mitochondrial differentiation and biogeography of Hyla meridionalis (Anura : Hylidae): an unusual phylogeographical pattern. Journal of Biogeography 34: 1207-1219.

Rensch B. 1929. Das Prinzip geographischer Rassenkreise und das Problem der Artbildung. Börnträger, Berlin.

Ridley M. 1993. Evolution. Blackwell, Oxford.

Ronquist F, Huelsenbeck JP. 2003. MRBAYES 3: Bayesian phylogenetic inference under mixed models. Bioinformatics 19: 1572-1574.

Sanderson S. 2004. r8s, version 1.70. Available at http://loco. biosci.arizona.edu/r8s/.

Steinfartz S, Vicario S, Arntzen JW, Caccone A. 2007. A Bayesian approach on molecules, morphology and behaviour: reconsidering evolutionary patterns of the Salamandridae with emphasis on Triturus newts. Journal of Experimental Zoology part B: Molecular and Developmental Evolution 308: 139-162.

Steward JW. 1969. The tailed amphibians of Europe. Newton Abbot, Devon.

Swofford DL. 2003. PAUP*. Phylogenetic Analysis Using Parsimony (* and Other Methods), Version 4. Sinauer Associates, Sunderland, Massachusetts. 
Swofford DL, Selander RB. 1981 BIOSYS-1: A FORTRAN program for the comprehensive analysis of electrophoretic data in population genetics and systematics. Journal Heredity 72: 281-283.

Thorn R. 1968. Les salamandres d'Europe, d'Asie et d'Afrique du Nord: description et moeurs de toutes les espèces et sousespèces d'Urodèles de la région Paléarctique d'après l'état de 1967. Lechevalier, Paris.

Veith M, Mayer C, Samraoui B, Barroso DD, Bogaerts S. 2004. From Europe to Africa and vice versa: evidence for multiple intercontinental dispersal in ribbed salamanders (Genus Pleurodeles). Journal of Biogeography 31: 159-171.

Wallis GP, Arntzen JW. 1989. Mitochondrial-DNA variation in the crested newt superspecies: limited cytoplasmic gene flow among species. Evolution 43: 88-104.

Whitfield JB, Lockhart PJ. 2007. Deciphering ancient rapid radiations. Trends in Ecology and Evolution 22: 258-265.
Wiens JJ. 2000. Reconstructing phylogenies from allozyme data: comparing method performance with congruence. Biological Journal of the Linnean Society 70: 613-632.

Wolterstorff W. 1923. Übersicht den Unterarten und Formen des Triton cristatus Laur. Blätter für Aquarien- und Terrarienkunde 34: 120-126.

Xia X, Xie Z. 2001. DAMBE: data analysis in molecular biology and evolution. Journal of Heredity 92: 371-373.

Zajc I, Arntzen JW. 1999. Phylogenetic relationships of the European newts (genus Triturus) tested with mitochondrial DNA-sequence data. Contributions to Zoology 68: 73-81.

Zardoya R, Malaga-Trillo E, Veith M, Meyer A. 2003. Complete nucleotide sequence of the mitochondrial genome of a salamander, Mertensiella luschani. Gene 317: 17-27.

Received: 19 August 2007

Accepted: 16 October 2007 


\section{Appendix I}

Material used in the present study. Shown are taxon name, origin of the sample, sample size and voucher information. ZMA = Herpetology Department at the Zoological Museum Amsterdam, The Netherlands. N.a. = not available.

\begin{tabular}{|c|c|c|c|c|c|c|c|}
\hline \multicolumn{2}{|c|}{ Population } & \multicolumn{2}{|c|}{ Coordinates } & \multicolumn{2}{|c|}{ Sample size } & \multicolumn{2}{|c|}{ Voucher at ZMA Herpetology } \\
\hline Taxon & Locality and country & latitude & longitude & allozymes & mtDNA & Collection number & Individual numbers \\
\hline \multicolumn{8}{|c|}{ Triturus cristatus } \\
\hline 1a & Canterbury, United Kingdom & $51^{\circ} 17^{\prime} \mathrm{N}$ & $01^{\circ} 05^{\prime} \mathrm{E}$ & 5 & 2 & 7802,9200 & $594,595,967,970,971$ \\
\hline $1 b$ & Peterborough, United Kingdom & $52^{\circ} 35^{\prime} \mathrm{N}$ & $00^{\circ} 15^{\prime} \mathrm{W}$ & 5 & 3 & 9144,9199 & $583,972,973,968,969$ \\
\hline 2 & Limanowa, Poland & $49^{\circ} 43^{\prime} \mathrm{N}$ & $20^{\circ} 25^{\prime} \mathrm{E}$ & 10 & 5 & 9135 & $584-593$ \\
\hline 3 & Sinaia, Romania & $45^{\circ} 20^{\prime} \mathrm{N}$ & $25^{\circ} 33^{\prime} \mathrm{E}$ & 10 & 10 & 9156 & $369-371,698-704$ \\
\hline \multicolumn{8}{|c|}{ Triturus carnifex carnifex } \\
\hline 4 & Fuscaldo, Italy & $39^{\circ} 25^{\prime} \mathrm{N}$ & $16^{\circ} 02^{\prime} \mathrm{E}$ & 11 & 5 & 7849,9108 & $340,405-414$ \\
\hline 5 & Kramplje, Slovenia & $45^{\circ} 44^{\prime} \mathrm{N}$ & $14^{\circ} 30^{\prime} \mathrm{E}$ & 10 & 4 & 9132 & $312-317,618,619,785,786$ \\
\hline \multicolumn{8}{|c|}{ Triturus carnifex macedonicus } \\
\hline 6 & Ano Kaliniki, Greece & $40^{\circ} 52^{\prime} \mathrm{N}$ & $21^{\circ} 26^{\prime} \mathrm{E}$ & 11 & 6 & 9085 & $602-605,658-661,674-676$ \\
\hline 7 & Višegrad, Bosnia and Herzegovina & $43^{\circ} 47^{\prime} \mathrm{N}$ & $19^{\circ} 20^{\prime} \mathrm{E}$ & 15 & 4 & 9168 & $896-909,962$ \\
\hline \multicolumn{8}{|c|}{ Triturus dobrogicus } \\
\hline 8 & Ečka, Serbia & $45^{\circ} 18^{\prime} \mathrm{N}$ & $20^{\circ} 27^{\prime} \mathrm{E}$ & 14 & 5 & 9104,9188 & $415-425,510,746,747$ \\
\hline $9 \mathrm{a}$ & Svištov, Bulgaria & $43^{\circ} 37^{\prime} \mathrm{N}$ & $25^{\circ} 21^{\prime} \mathrm{E}$ & 2 & 2 & 9160 & 459,748 \\
\hline $9 b$ & Zimnicea, Romania & $43^{\circ} 40^{\prime} \mathrm{N}$ & $25^{\circ} 22^{\prime} \mathrm{E}$ & 2 & 2 & 9171 & 336,705 \\
\hline \multicolumn{8}{|c|}{ Triturus karelinii } \\
\hline 10 & Bartin, Turkey & $41^{\circ} 37^{\prime} \mathrm{N}$ & $32^{\circ} 20^{\prime} \mathrm{E}$ & 10 & 5 & 7564 & $116-125$ \\
\hline 11 & Grivac, Serbia & $43^{\circ} 58^{\prime} \mathrm{N}$ & $20^{\circ} 40^{\prime} \mathrm{E}$ & 9 & 5 & 9115 & $817-824,893$ \\
\hline 12 & Rakovski, Bulgaria & $42^{\circ} 16^{\prime} \mathrm{N}$ & $24^{\circ} 58^{\prime} \mathrm{E}$ & 4 & 4 & 9149 & $515,766-768$ \\
\hline \multicolumn{8}{|c|}{ Triturus marmoratus } \\
\hline $13 \mathrm{a}$ & Confolens, France & $46^{\circ} 01^{\prime} \mathrm{N}$ & $00^{\circ} 40^{\prime} \mathrm{E}$ & 1 & 1 & 9095 & 518 \\
\hline $13 b$ & Rochechouart, France & $45^{\circ} 49^{\prime} \mathrm{N}$ & $00^{\circ} 50^{\prime} \mathrm{E}$ & 4 & 3 & 9151 & $535-538$ \\
\hline 14 & El Berrueco, Spain & $40^{\circ} 54^{\prime} \mathrm{N}$ & $03^{\circ} 53^{\prime} \mathrm{W}$ & 7 & 5 & 7614 & $161-167,980-982$ \\
\hline \multicolumn{8}{|c|}{ Triturus pygmaeus } \\
\hline 15 & Rio Alberite, Spain & $36^{\circ} 24^{\prime} \mathrm{N}$ & $05^{\circ} 39^{\prime} \mathrm{W}$ & 20 & 3 & 7552,7618 & $77-95,180$ \\
\hline 16 & Venta del Charco, Spain & $38^{\circ} 12^{\prime} \mathrm{N}$ & $04^{\circ} 16^{\prime} \mathrm{W}$ & 10 & n.a. & 7677 & $282-291$ \\
\hline \multicolumn{8}{|c|}{ Calotriton asper } \\
\hline 17 & Berga, Spain & $42^{\circ} 06^{\prime} \mathrm{N}$ & $01^{\circ} 50^{\prime} \mathrm{E}$ & n.a. & 2 & n.a. & \\
\hline 18 & Valle Hecho, Spain & $42^{\circ} 44^{\prime} \mathrm{N}$ & $00^{\circ} 45^{\prime} \mathrm{W}$ & n.a. & 2 & n.a. & \\
\hline
\end{tabular}

\section{Appendix II}

Twenty-two different ND4-haplotypes (h01-h22) were observed. Their corresponding GenBank accession numbers are AM900468-89. The haplotype distribution over populations and individuals is as follows: h01 - Canterbury, specimens 594 and 595; Limanowa 589-593; Sinaia 369-371, 698-701, 703, 704; h02 - Sinaia 702; h03 - Fuscaldo 405-409; h04 - Kramplje 312-314, 786; h05 - Ano Kaliniki 602, 658, 659, 675, 676; h06 - Ano Kaliniki 604; h07 Ečka 415; h08 - Ečka 416; h09 - Ečka 417, 418, 419; Zimnicea 336, 705; Svištov 459; h10 - Svištov 748; h11 - Bartin 121; h12 - Bartin 118, 124; h13 - Bartin 116, 123; h14 - Grivac 821-824, 893; Rakovski 515, 766-768; Višegrad 898; h15 - Višegrad 896, 897, 899; h16 - Confolens 518; Rocheouart 535, 536, 538; h17 - El Berrueco 161; h18 - El Berrueco 162, 980-982; h19 - Rio Alberite 77, 80, 81; h20 and h21 - Berga and h22 - Valle Hecho. For voucher information see Appendix I. 